\title{
Utilizing Social Media In Partai Solidaritas Indonesia (Psi) As Youth Political Party
}

\author{
Irene Silviani, Rehia K.I Barus, Nadra Ideyani Vita, Bimby Hidayat \\ Universitas Darma Agung, Universitas Medan Area, STIK-P \\ Email: irenesilviani@gmail.com
}

\begin{abstract}
This research raise, elaborate and analyze Generation "Y" or Millenials political communication in establishing Partai Solidaritas Indonesia (PSI). Politic has transformed from mass movement to social media movement. This matter certainly different from society tradition to respond politic and government policy in the past. Since social media grow rapidly. Since then also generation "Y" or Millenials changed to social media. "Y" Generation or Millenials is youth generation born between 1980 to 2000. PSI is the only political party that pass in Ministry of Law and Human Right verification announcement on October $7^{\text {th }}, 2016$. Where the main requirement for PSI stewardship is young people aged below 45. This research formulation of the problem is How the youth political communication pattern that able to utilize social media as member recruitment media to fulfill the requirement for establishing a political party. This research uses political communication approach, political party theory, and generation theory. This research is a qualitative research with positivist paradigm with description analysis in explaining the new phenomenon in the mass transformation to social media transformation in politic. The result of this research shown that social media is very effective in political communication media especially in propaganda, agenda setting and promoting PSI as youth political party. Next social media is also very effective in uniting every individual in an organizational communication network in PSI.
\end{abstract}

Keyword: Political Communication, Political Party and Millenial Generation

\section{PREFACE}

Politic has transformed from mass movement to social media movement. This matter certainly different from society tradition to respond politic and government policy in the past. For instance in the matter regarding the campaign, Political party vision-mission and demonstration in response to nonpro-society policy done by going right to the street. This matter is what seems contrasting nowadays. Since social media grow exponentially in Indonesia. Since that also the activity of "Y" generation or Millenials turned to social media. "Y" Generation or Millenials is a generation of young people born between 1980's - 2000's.

Since Social media grow exponentially in early 2000's. Like; Friendster (2002), Facebook (2004), MySpace 2006, Twitter (2007) until Path (2011). Practically human activity shifted toward the digital world. This exponential growth of social media caused the term Netizen to pop out. Where the word Netizen come from the word Net which refers to Internet and Citizen. If defined means the people of the Internet. Which mean netizen is every one access and uses the internet. In this era, the utilization of internet through social media is not only related to the online shop and product promotion only. Social media utilization already lead toward matters that are social and politics.
Like forming an image of the head candidate of a region or even president candidate, political party campaign also functions as mean of interaction by politician and its constituent. As a new political party that carries the brand of youth political party. Surely the need for social media will become crucial remembering that social media user is dominated by young people that are also Millenials. ${ }^{1}$

On the other side according to Institute for Transformation Studies (Intrans) entitled"Partai Politik Paling Berpengaruh di Media Social" on Jakarta 30 March 2016. Stated Partai Solidaritas Indonesia (PSI) in the first rank for content in Facebook social media with most likes. Whereas much as 637.000 likes put Partai Solidaritas Indonesia (PSI) in top position. Followed by Gerindra with 472.000 likes, PDI Perjuangan 222.000 likes, Partai Demokrat 67.100 likes and Partai Keadilan Sejahtera 649.000 likes. $^{2}$

\footnotetext{
1 Artikel Anwar Saragih di Geo Times : Grace Natalie dan Jawaban Politik Generasi "Y"

http://geotimes.co.id/grace-natalie-dan-jawaban-politikgenerasi-y/ downloaded on 25 september 2016, 12.00 wib.

${ }^{2}$ Harian Merdeka online Survei Intrans: Partai Solidaritas Indonesia paling kuat di medsos

http://www.merdeka.com/politik/survei-intras-partaisolidaritas-indonesia-paling-kuat-pakai-medsos.html
} 
On Friday, 7 October 2016 Ministry of Law and Human Right (Kemenhum HAM) officially announced the verification result of political party incorporated. Partai Solidaritas Indonesia (PSI) become the only new party that passes the verification from 5 political party that register to Kemenkum HAM on 24 May 2016 24 July 2016. Those five parties are Partai Rakyat, Partai Pribumi, Partai Idaman, Partai Beringin Karya dan Partai Solidaritas Indonesia (PSI). Means that have fulfilled term and condition on Undang-undang nomor 2 tahun 2011 about the Political party and Peraturan Menteri Hukum dan HAM nomor 37 tahun 2015 about the procedure of establishment of legal entities, AD/ART changes, also changes of political party stewardship.

Where a political party must also fulfill $100 \%$ stewardship at Provincial level, $75 \%$ stewardship in City level. Moreover, 50\% stewardship in the district in all region of Indonesia. All those requirements are not just a pile of the file but need to be proven factually regarding the truth. Further more PSI has officially become the 73rd legal, political party in Indonesia.

As a new party with youth political party brand. Appreciation regarding the pass of PSI as a legal, political party immediately fills social media timeline. Because only hours after the announcement for the passing of PSI as the only new party that pass Ministry of Law and Human Right verification created the hashtag \#PSIsatu2nyaPartaiBaru become a trending topic on twitter. Further more, in 7 days after the announcement of verification result hashtag \#PSIsatu2nyaPartaiAnakMuda,\#PSIsatu2nyaPar taiMasaDepan,\#PSIsatu2nyaPartaiPerempuan, and \#AnakMudaPilihPSI everyday kings the trending topic on twitter. Mean that only in around one week Partai Solidaritas Indonesia (PSI) become the talk of netizen in social media.

This condition seems inversely proportional to the publication of several survey institute that had released before about the trust of society toward political party that decreased by time. Especially for youth segment that is considered apathetic and did not care about politic. Even further more, several political observers stated this condition is very critical in the mean that what ever the political party did would still be considered as wrong. This thing is very harmful to the future of Indonesia in the future. Because the political party is the only one source of national leadership recruitment that from it also born a president as policy executor and House of representatives (DPR) as a regulation maker. Mean hope for better leadership has to directly proportional to the trust interest of public toward politic. In this part, PSI as a political party succeeded to captivate social media user which dominated by young people.

In this position seen that Partai Solidaritas Indonesia (PSI) born as the embrio of youth political party that answered Millenial needs. PSI could also become the answer for the paradigm identical to Millenial are the outcast generation. Because the behavior of young people using the gadget, taking a selfie, bullying, and showing off their private life in social media construct a thinking construction that Millenial is unproductive, lazy, and had no influence toward the development of this nation and country.

However, According to data by Asosiasi Penyelenggara Jasa Internet Indonesia (APJII) that release the latest user statistic and internet user behavior in Indonesia until 2016. Internet user consists of 132, 7 million from the total population of 256,2 million Indonesia people. From those total, around $49 \%$ is a young generation born between 1980's - 2000's. That mean social media world was ruled by Millenial.

The closeness between Millenials and Internet could not be seen trivial. Because according to a prediction by Badan Pusat Statistik (BPS) in 2020-2035 Indonesia would get a demographical bonus. In population, projection recorded that number of population in Indonesia on 2035 as much as 305,6 million life with the percentage of a productive working generation reaching $66,6 \%$ which is Millenials generation.

The demographical bonus is a condition where composition amount of productive people is larger than nonproductive people. The category of productive working generation aged 15-64, While the nonproductive generation aged $0-14$ and above 65 . That mean potential held by Millenial generation toward nation development would be very big in the future. For that what becomes the question in this research is how is the strategy of utilizing social by Partai Solidaritas Indonesia (PSI) as Youth Political Party? 


\section{RESEARCH METHODOLOGY}

This research uses the qualitative method. Where researcher collects data through deep interview with various interviewees that have the capacity and capability related to the organizer of the general election and general election supervisor. Where in deciding the interviewees using Purposive Sampling technique in interviewing Central Board Secretary of Partai Solidaritas Indonesia Raja Juli Antoni, Secretary of Regional Head Council of Partai Solidaritas Indonesia Sumatera Utara Fuad Ginting and Academics of Universitas Sumatera Utara Fernanda Putra Adela,S.Sos, MA. The researcher also collects various form of other qualitative data that are useful for deeper understanding in this research.

\section{RESEARCH RESULT}

\section{A.Agenda Setting}

Social media is an important factor in socialization effort of thought or idea even in doing persuasion toward the public. The existence of good social media helps PSI in giving information or idea toward public which is spreading goodness, maintaining diversity and strengthen solidarity. Not only that, for major part of the group, social media become important for Social public media to have become more than just giver of information and opinion. Social media have successfully pushed PSI to decide what needs to be considered. In this matter, PSI agenda setting has successfully campaign diversity. The diversity of ethnic group become national cultural sources. An ethnic group is a group of people bond by culture, language, and residence. Because of that, every ethnic group has a different language. Tradition and culture are also different. i.e., Asmat tribe living in West Irian, they use Asmat language and culture. Asmat tribe is different from Batak tribe. Batak Tribe lives in North Sumatra. Batak Tribe uses Batak language and culture.

Social media can legitimate Partai Solidaritas Indonesia (PSI) substantially exist as a political party that upholds diversity highly not just in words but becoming the fundamental principle PSI in organization and movement. This becomes a fundamental principle that must be understood by every cadre in every level.

Indonesia is a form of diversity itself, Indonesia is a mosaic which forms by ranges of tribe, religion, culture. PSI realize that Bhinneka tunggal Ika (Unity in Diversity) is a principle that constantly becomes political breath in every program and movement. The difference is godly destiny that could not be changed; diversity is historical destiny for Indonesia. For that PSI as a new political party always urge their cadres to give a high honor toward that diversity and accepting it as a godly destiny and historical destiny. ${ }^{3}$

According to Raja Juli Antoni that stated; "Social Media especially Twitter and Facebook are very effective in campaigning PSI. In this position PSI as a youth political party brand utilizing it maximally."4

\section{B.Leading Public Opinion}

Public opinion is an opinion by a group of people or synthesized from a person and acquired from a social discussion from the part that has related interest. Aggregate from this attitude and trust is mostly embraced by Adults population. In deciding public opinion, What is count is not the numerical majority but effective majority. Public opinion subject is a new controversial problem where elements of public opinion are: controversial statement, about something contradictive, and first reaction / new idea.

Principle approach toward the study of social media role in leading public opinion regarding communication media that bring up the idea that becomes base opinion as well as utilizing media by propaganda and manipulation victim. The opinion could also state behavior, body language, mimic, written symbol, outfit used, and by another unlimited symbol, through References, Values, View, Attitude, and Loyalty. Public Opinion is identical with the definition of freedom, openness in expressing ideas, opinion, desire, complaint, constructive critic, and freedom in writing. In another word, Public opinion is the effect from the freedom of expressing ideas and opinion in society. ${ }^{5}$

In this matter, PSI has formed a general opinion in leading opinion, One of the most powerful channels in forming public opinion through twitter, Instagram, and Facebook. Because with a public opinion have the power to change existing political system by constructing public attitude and action toward a political problem and political actor. In this frame, media

\footnotetext{
${ }^{3}$ ABC PSI., Op.,Cit., Hal.14.

${ }^{4}$ Wawancara dengan sekretaris DPP PSI Raja Juli Antoni, di kantor DPW PSI Sumut pada 1 agustus 2016, pukul 18.00 wib.

${ }^{5}$ http://generasi-rabbanimadani.blogspot.com/p/pengertian.html downloaded pada tanggal 21 september 2016 , Pukul 12.34 Wib
} 
deliver political talks to the public. A form of those political talk in media is in political text or news which again inside of it contain choices of political symbol and fact.

Secretary of Regional Head Council Partai Solidaritas Indonesia Fuad Ginting stated:

"PSI was born as a new political embryo in Indonesia that emphasize diversity. This is done for a reason where Indonesia was tailored from various ethnic, religion, and culture. Indonesia this day is having a diversity crisis where we saw many intolerant actions regarding the destruction of the house of worship, Racisme, and Tribal conflict is still happening in reformation era. The understanding of that diversity is socialized through social media." 6

The statement was strengthened by Fernanda Putra Adela that stated;

"I saw PSI reporting depend on social media regarding an introduction. This, of course, becomes something new remembering that I read the stewardship were all below 45." 7

\section{DISCUSSION}

The development of social media keeps growing. The ability to master and utilize it will become a strategic factor for political actor in communicating and campaigning process of their politic. Support and vote acquisition is the main target of every political actor. Moreover, have become identical ( for not saying a linear matter and absolute matter) that the most popular political actor in social media, is the one getting the most support and vote by the public. This is the biggest positive impact from social media in political communication and campaign process. Social media is giving positive effect to the political actor by the intense two-way political engagement with the supporter of Jokowi - J.K.

PSI is a youth political party that is close to social media in their campaign. Partai Solidaritas Indonesia (PSI) offers newness in

\footnotetext{
${ }^{6}$ Wawancara dengan Fuad Ginting Sekretaris DPW Partai Solidaritas Indonesia (PSI) di Rumah Solidaritas di Jalan karya kasih tanggal 25 juli 2016, pukul 18.00 wib.

${ }^{7}$ Wawancara dengan Akademisi Universitas Sumatera Utara Fernanda Adela Putra (Dosen Ilmu Politik USU) pada tangal 1 september 2016 di kediamannya pukul 10.00 wib.
}

Indonesia politic with the stewardship under 45 and never become other political party member before. Mean Partai Solidaritas Indonesia (PSI) wanted young people that are new in the politic world. Beside that PSI also uses youth term in every activity such as "Kopi Darat Nasional (Kopdarnas)" that refer to the term Musyawarah Nasional (Munas) that are most used by another political party, such as: PDI Perjuangan, Golkar, and another political party. Also the term "PSI Kepoin Pilkada" that refer to PSI attitude in monitoring Simultaneous Regional Head Election held on 9 December 2015 that show this party is a youth political party.

The stewardship of Central Head Council of Partai Solidaritas Indonesia (PSI) itself consists of 9 people, and most of the people are not familiar with National Politic activity. Such as; Grace Natalie (General Head), Raja Juli Antoni (General Secretary), Suci mayang Sari (General Treasurer), Isyana Bagoes Oka (Head of Central Head Council), Nova Rini (Head of Central Head Council), Danik Eka Rahmaningtiyas (Vice Secretary General), Satya Chandra Wiguna (Vice Secretary General), Sumardy (Head of Central Head Council) dan Danik Eka (Head of Central Head Council.

\section{CONCLUSION}

The usage of mass media in political communication is very appropriate with the effort of forming candidate and political party image to get support from the public. Mass communication with the basic characteristic such as general, open, and actual. Mass communication message is actual which happen in term of time, happen in term of substance. That is what cause mass communication has a very big relation between politic and communication.

As the party for youth PSI needed social media Because through social media their political message will be delivered implicitly. As the new party with the brand of youth political party. Appreciation regarding the pass of PSI as a legal, political party directly fills social media timeline. Because only hours after the announcement for the passing of PSI as the only new political party that pass Ministry of Law and Human Right verification the hashtag \#PSIsatu2nyaPartaiBaru immediately become a trending topic on Twitter. Furthermore, in 7 days after the announcement the hashtag \#PSIsatu2nyaPartaiAnakMuda,\#PSIsatu2nyaPart aiMasaDepan,\#PSIsatu2nyaPartaiPerempuaand \#AnakMudaPilihPSI every single day reach trending topic. Which mean only around a week 
Partai Solidaritas Indonesia (PSI) become the talk of many people in social media.

The struggle for PSI surely not only in social media. Because In the future PSI still should face verification done by General Election Commision (KPU) as the main requirement for being a participant in 2019 General Election. Referring to Constitution No.8 2012 about General Election, To pass the verification of General Election Commision. Partai Solidaritas Indonesia (PSI) should have at least 1.000 members or $1 / 1.000$ from the population of a city. Mean in the future this becomes the challenge for young PSI cadre as a new party in utilizing social media. Hard work, Sincerity, and the ownage toward PSI itself.

\section{REFFERENCES BOOK:}

Firmanzah, Mengelola Partai Politik, Jakarta : Yayasan Obor, 2008

Jefkins, Frank, Public Relations. Edisi Keempat, Jakarta: Penerbit Erlangga, 1992.

Wirawan, Wisnu, Mempersuasi Massa Dengan Agenda Setting Theory, 2001.

\section{INTERVIEW :}

Wawancara dengan Fuad Ginting Sekretaris DPW Partai Solidaritas Indonesia (PSI) di Rumah
Solidaritas di Jalan karya kasih tanggal 25 juli 2016, pukul 18.00 wib.

Wawancara dengan Akademisi Universitas Sumatera Utara Fernanda Adela Putra (Dosen Ilmu Politik USU) pada tangal 1 september 2016 di kediamannya pukul 10.00 wib.

Wawancara dengan sekretaris DPP PSI Raja Juli Antoni, di kantor DPW PSI Sumut pada 1 agustus 2016, pukul 18.00 wib.

\section{ONLINE REFFERENCE;}

Artikel Anwar Saragih di Geo Times : Grace Natalie dan Jawaban Politik Generasi "Y" http://geotimes.co.id/grace-natalie-danjawaban-politik-generasi-y/ diunduh pada 25 september 2016, pukul 12.00 wib.

Harian Merdeka online Survei Intrans: Partai Solidaritas Indonesia paling kuat di medsos http://www.merdeka.com/politik/survei-intraspartai-solidaritas-indonesia-paling-kuat-pakaimedsos.html diunduh pada tanggal 25 september 2016 pukul 13.02 wib.

http://generasi-rabbanimadani.blogspot.com/p/pengertian.html diunduh pada tanggal 21 september 2016 , Pukul 12.34 Wib 